\title{
Non-Usury Banking Fits the Change Strategy: The Solution to Revive the Economy
}

\author{
Bijan Bidabad \\ B.A., M.Sc., Ph.D., Post Doc. \\ Professor of Economics and Chief Islamic Banking Advisor \\ Bank Melli Iran, Tehran, Iran \\ Email: bijan@bidabad.com
}

\begin{abstract}
Based on the working in different fields of sciences for a long time, a solution to change the structure of banking products as a solution to economic crises is proposed. By sharing the risks economically this solution can make economic integrity among all economic sectors.In this paper, we are going to introduce a new Islamic financial institution with elaborated economic and financial characteristics. «Non-Usury Bank Corporation» (NUBankCo) is defined in a way that depositors are the shareholders of the Bank. This corporation is a new kind of shared ownership corporation, which its shareholders are deposit holders and their deposits work as corporation's equities. The defined bank can perform non-usury operations, and by designing a behavioral model, it is shown that NUBankCo can draw an environment that the welfare of society is to be maximized. Mobility of deposit resources in NUBankCo is less than conventional banks, and there are fewer conflicts between large and small shareholders/depositors and limits the emergence of shareholders' cartels and thus huge sudden outflow of funds which creates bankruptcy crises.
\end{abstract}

Keywords: Usury, Islamic Banking, Finance, Rastin Banking, Profit and Loss Sharing

\section{Introduction}

The recent economic recession was predictable for a few years before, even if its depth cannot be imagined yet. A new solution matching the current turmoil was being confectioned for several years to remedy this type of economic crises. In these crises, the monetary policy would not be efficient enough, and fiscal policy is not a fast recovery remedy. Thus, the protectionism policy should be attained to solve the problem for the long run. Refection of the financial system is the most important step to make.

The Profit and Loss Sharing (PLS) banking is the method to replace actual usuric traditional banking. PLS banking not only can regain the trust of investors and depositors to the financial market, but also will reduce costs of investment and production by reducing the risks of investment and producing stable markets. In this paper, the other positive effects of PLS such as the creation of new job opportunities, easy flow of capital and transactions, an increase of investments and productivity resulting to Global Wealth and the attenuations of international political complications also equity and peace, will not be explained.

Today, the global economy shows the lowest interest rate and the United States economy's recession is being propagated to west and east of the world, where the recent increase of oil price caused the markup prices grew at the global level, and the expensiveness has been prevailed in public sustenance, especially for food grains. The bankruptcy and deficits of some western globe banks and higher financial risks at international financial markets and sequential crises in these markets illustrate a crisis similar to the 1929 world crisis. However, this one was accelerated by several impacts on the economy, such as natural disasters in West and risk-increasing Bush's policies in the East. Based on detailed economic researches, it has been proved that the volatilities of financial sector cause the fluctuations of the real economy and starts business cycles. In the 1929 crisis, investment and saving inconsistency in western economies, especially in the United States pushed the global economy to the phenomenon of the liquidity trap. There were only negative interest rates that were able to motivate the economy to pull it up from the bottom of the cycle. The monetary policy did not work because the interest rate was too low to be pushed to lower rates by increasing the money supply. When the economy falls into the liquidity trap, there is no monetary policies solution via either increasing the volume of liquidity or decreasing the interest rate to motivate investment demand to recover the economy back to prosperity. Principally, a liquidity trap is caused due to a weak relationship between the rate of return in the real sector and the interest rate in the monetary sector; when the interest rate moves 
to lower rates but nominal investment rate of return does not. One reason for such occurrence is the increase of investment risks, which decreases the net return of capital. The risk becomes a wide premium of capital market's interest rate and investment market's return rate. On the other hand, the difference in the interest rate and investment rate of return increases.

The president of the United States of America, Mr. Barak Hussein Obama's "Change Strategy" is a worthy decision to be taken at this point in time. This decision would change the world economy as well if it becomes successful in changing the economic infrastructure of the United States. If his policy ends to monetary sector reform, he will be able to revive the economy from the deep crisis; because the business cycle happens because of increase of risk in financial markets due to usury financial systems.

If the risk and the profit of investment were shared with depositors, financial enterprises would be confronted with the lowest risk, and the risk would be transferred to depositors and debtors both, so the real and the financial sectors will be immunized from volatility. The solution is to peg the interest rate to real economy return rate. Whereas by sharing the risk and the profit, the distance between the real sector and financial sector rates is reduced, and the premium of the risk will diminish. This will enable investment with lower cost for production. In fact, where the monetary solutions cannot be efficient (like the current situation) by application of risk sharing, we can balance and revive the economy. This is why theosophically divine religions pose: "Usury is forbidden".

A solution to solve this deficiency has been expressed by religious legislators through deletion of usury from the economy. The religious legislation in Torah and Bible and Quran actually have removed the intermediate monetary market between depositors and investors by the prohibition of usury and establishing a proportional relationship between profit and loss of investors (debtors) and the receipts of depositors. Thus, it is not an exaggeration to say that the solution to prevent a global crisis similar to the previous century crisis is to change the nature of usury in the monetary sector and establishing profit and loss sharing between depositors and investors (entrepreneurs). Real sector return rate is a stable rate, due to the stability of productivity and will not fall down or rise up drastically. Establishment of profit and loss sharing will stabilize the interest rate due to the strengthening of the link between the interest rate in the money market and the rate of return of investment in the real sector. Thus, inconsistency between investment and saving and, also, the liquidity trap will not happen in the economy to push the economy to the crisis. Although the business cycle will not vanish from the economy, the cycles' swings will have narrow volatility domain.

Many countries have taken important steps to establish profit and loss sharing (PLS) banking systems. Regarding the lower risk of this type of banking, some western countries have been interested in testing this non-usuric banking system for the sake of risk averting. According to the IMF reports, Islamic banking has increased 10-15\% annual growth in the last decade, and the same growth is predicted for the future years.

Despite the interest of bankers for using Profit and Loss Sharing (PLS) banking for the last decades, it has not prevailed yet executively. The existence of different definitions of Riba, absence of appropriate operational, supervisory, and managing mechanism on PLS are some reasons that haven't allowed this kind of banking to be practical yet.

Here, we are going to introduce a practical method for Profit and Loss Sharing (PLS) banking to overcome these problems. In this bank, the basis of determination of interest rate of loans is the real economy sector return. The bank operates as an intermediate that gets commissions and collects saving resources and as an attorney or legal representative of depositor allocate them to investment projects and supervises the detailed operation of the contractor. The yields of an investment will be transferred to resources owners who are depositors whatever the profit or loss is.

\section{Profit and Loss Sharing based on Non-Usuric Banking Products}

Despite many developments and endeavors, PLS banking has not been settled down operationally. The obstacles are due to needs to apply suitable executive mechanism and operation's procedures. In the way of applying PLS, its procedures all the times have been mixed with usuric banking and even its financial instruments (innovations) as "profit and lost sharing certificate" and "investment deposit certificate" which attracted attention in the late 1990s were left aside. This contamination occurred due to some reasons. The most important one was due to executive and supervision problems on the operation of entrepreneurs who receive the financial resources for PLS, in all financial, economics, technical and executive aspects; because, the banks have not been organized to supervise the detailed operations of the investments. Thus, they were not qualified to do the task of supervision on operations. Therefore, the banks manipulated non-usury rates into interest rate and actually, they entered the interest rate into the calculation - though the existence of usury was not very obvious in the calculations. But by scrutinizing the loan calculations, the amount of interest was computable. Another problem is: the juristic inferences about usury in different Islamic sects are different, and this subject caused some differentials in usury definitions. Different definitions produced different non-usuric banking products at an international level, in a case that some of these 
products were not consistent with similar products of other banks. Even in Iran, where the consistency was more than other countries the same result happened and also the jurist's and economists' consensus in the time of approving "The law of non-usury banking" in the early 1980s went to conflicts.

Thus, the general solution for the establishment of original non-usuric banking needed to revise the whole problem from the basis. The present proposition is the result of tough researches during the last ten years. We did our best to infer the opinion of religion's legislator according to the logic and rationality of theosophy (wisdom). We tried to reinfer the concept of usury from the Torah, Bible, and Quran, and narrations first. Thus some measures for distinguishing usury from non-usury were defined. These measures explicitly define the non-usuric operations as the following items:

- The sharing of a loaner in Profit and Loss of loanee (the debtor)

- No conditioning and not predetermination of interest

- Foreign exchange (without time-based interest) is non-usuric

- All interests received from consumption loans are usuric

By these measures, in the next round, we examined the Islamic banking products. Deposit, loan, currency exchange, bonds, valuable papers and metals, receive and payment orders and credit operations were analyzed according to the above usury and non-usury measures. Some products as Foroosh-e-Aqsati, Ijareh-be-Sharte-Tamlik, debt purchase and sale, and composite interest derived from the inability of loanee to repay the debt are usuric. Also giving loan facilities through non-interest loan, civil Moshareka, legal Moshareka, direct investment, Modaraba, Salaf transaction, Jjiale, Mozaraeh, Mosaghat, Ijarah, according to specific conditions are non-usuric. In all of these products except non-interest loan and Ijarah, which the rate of Ijarah should be predetermined in advance, the interest rate must not be determined and conditioned. Otherwise, the contracts become usuric. Foreign exchange operations in spot and swap transactions (in case of not-existing interest rate in exchange calculations), options (in case of a unique interest rate for two currencies), letter of credit are non-usuric. But the foreign exchange operations of futures and time-based transactions timed swap transactions; options and foreign exchange deposits enter into usury realm. We examined all sale and purchase of bond papers, metals' transactions, receipt and payment order, and banking credit operations and their characteristics from the usuric point of view.

3. NUBankCo; the Ultimate Idea is now feasible

According to the findings of these analyses, the concept of "Non-Usury Bank Corporation (NUBankCo)" introduced which can handle non-usuric banking operations. NUBankCo was proposed as an economic firm where the depositors are her shareholders. This bank is capable of handling non-usuric operations by distributing profit proportionate to the share of shareholders (depositors). If the banks remove different deposits differentials and increase transparency and efficiency of banking operation, by removing the numerous deposit interest rates and increase the participation in economic activities, and if both private and public, legal or real persons were able to participate, this will result to the efficiency of financial intermediary role of the bank in collection and allocation of financial resources.

The growth of information and communication technology (ICT) prepared suitable backbones for the development and improvement of this type of banking. Thus, by reanalyzing the problem with ICT considerations, the whole problem was revisited. We tried to link financial accounts of loanees to bank databases through IT. In case of establishment of this link, profit and loss calculations, also bank supervision over the investment operations of investors (loanee) becomes feasible. The latter is the main obstacle in designing profit and loss sharing banking. In this stage, we tried to design integrated systems through digital channels to encompass all affecting factors in banking operations and supervisions as a chain and the real return of deposits (investment) of depositors to be distributed through secure digital channels. By using Enterprise Resource Planning systems (ERP), Customer Relationship Management (CRM), Supply Chain Management (SCM), Management Executive Systems (MES), Human Resource Management (HRM), Business Process Re-engineering (BPR) and Work Flow Management (WFM) as core banking modules for non-usuric banking we examined this integrated design. By this design, the commercial partners, depositors, banks, central banks, Real-time Growth Settlement System (RTGS) investors, financial markets, digital signatures authorities and also social security organizations and government were linked through information and communication technology systems. This connection could cause transparency of profit and loss sharing banking, and by using an integrated automatic system the information of depositors-bank-investor's triangle might be designed in a way that the sharing in profit and loss of financial operations for the three groups of the triangle happens. But, unfortunately, nowadays, weak facilities and equipment of companies were obstacles to making this idea feasible and operational. This idea will still remain un-operational for all size enterprises up to the time the interested commercial partners establish sufficient development in IT-based procedures. But the idea is currently operational for highly developed stock market digitally based companies. 


\section{NUBANKCO: The implementation Method}

All these findings in these fields by presenting some papers at national and international conferences were discussed, and we got elegant comments from these processes. We understood that to solve profit and loss sharing (PLS) mechanism; we should design a new solution to fit nowadays needs and be consistent with contemporary workflows in legal operational and IT aspects. For these reasons, we tried to design a new method for making PLS Banking operations. The new design is as follows:

Disregarding the public or private bank ownership, we should find a solution that interest rate be determined according to the real sector return rate, and the bank becomes as intermediate of resources who receive Haq-ul-Amal (a fee to follow and care the depositors' rights and benefits by offering capital management services to depositor and supervising on the agent's (entrepreneur's) operations who make investment based on deposits of depositor(s)). The bank in the position of an attorney or an agent receive capital management services fee and will transfer the investment returns (profit or loss) to the depositor. According to this definition, the agent bank as public or specific attorney by using Moshareka contract can use deposited deposits in shape of Moshaa (joint) and/or based on the depositor's request in specific product (of type 1 or 2) or based on banks opinion (in product type 3) invest in the project or projects and distribute the return of investment among depositors. The profit and/or loss will be distributed among them according to the pre-written related instructions. In this relation, the bank does the task of financial intermediary, and after deducting her wage, as an attorney or agent will pay the depositors' shares to them. Finally, we designed the operational sketch, and Bank Melli Iran (the biggest and oldest Iranian bank) proposed to put one of its important branches to implement the pilot project and test PLS banking at her own cost and risk. The system was designed for three banking products:

- Moshareka (sharing Profit and Loss) on specific projects

- Moshareka (sharing profit and loss) on a basket of some projects

- Moshareka (sharing profit and loss) on the profit and loss of the bank's branch which implements PLS banking.

In a Jiala-based contract, the bank will make a contract with depositors to allocate their deposits to one of the above three products according to their requests to get shares in profit and loss of the entrepreneur who implements the project. In the other side of the bank, an entrepreneur is who has requested to make a contract with the bank in a Moshareka-based contract. In this way, the bank operates as an intermediate that receives Haq-ul-Jialah or Haq-olAmal and allocates the deposit resources of depositors to investors. Depositors, in this case, are financers and investors are those who do the entrepreneurship of the investment. The profit and loss of this investment will be distributed among depositors, investors, and bank. Bank by offering this service can earn some share of profit/loss of these investment project as same as capital services management fees. That is in PLS banking, the contracts between bank and depositors and between bank and investors (entrepreneurs) can be performed based on Karmozd (wage) as well as sharing on profit and loss.

An entrepreneur is a legal person who combines her (cash or none-cash) capital with the share of depositors in a Moshareka based contract through bank intermediary to arrange a joint investment.

In this method, a trustee agent (Amin) is a unit who supervise the contractor operations on behalf of the bank for being honesty in carrying out the project, controlling on executive operations along with announced programs, resources allocation manner, and auditing financial statements. Amin (trustee) is an institution who supervise the PLS process as a representative of Bank about the good governance of the project, controlling the implementations according to the declared plans, allocation of resources, optimal use of resources, ... by using key indicators and financial sheets auditing.

In Profit and Loss Sharing (PLS) banking, the new financial innovations are used. PLS banking will use new financial instruments and innovations such as Moshareka (partnership) certificates for projects with specific ends and Pazireh (subscripted) certificates for endless (productive) projects. Establishing of secondary exchange market for the transaction of certificates, and various insurance services will play important roles for activating and increasing the efficiency of newly established virtual markets

The bank by issuing and offering the Moshareka certificates and creating secondary markets for transacting Moshareka certificates and designing baskets of Moshareka certificates will efficiently activate this type of baking and also the other related financial institutions. Implementing these arrangements needs particular instructions. We have written the necessary instructions to perform the job. Moshareka Certificate is no name papers issued by PLS banking branch with a specific nominal price for a definite time (project implementation duration). Moshareka Certificate holders will share profit and loss of project prorated to their nominal price and time duration of their Moshareka (participation). The bank will deliver a certificate of Moshareka and/or receive a service fee for capital management services to depositors, which will be according to one of the above three products. Moshareka Certificate holders can transact these papers through the internet or bank counter in the cyber environment, and thus, 
this certificate can be transacted internationally as a financial asset.

Depositors by accessing through information portal of internet station in the secondary market of Moshareka Certificates or by going to one of the branches of the bank performing the PLS banking and by receiving the consultation of the bank experts in the information counter will be familiarized with different Moshareka products and their conditions and regulations for depositing. Then she will decide to select one of the products of the three mentioned Moshareka products. By making the contract and the registration, the system will automatically issue the Moshareka Certificate, and the Moshareka Certificate will be accessible for the depositor. At the end of Mosharekeh period (for the products 1 and 2 regarding a single project or a basket of projects), or at the end of the financial year (regarding Moshareka in profit and loss of the branch who perform the PLS), accounting/auditing counter by receiving the related information will calculate profit and loss of the project or basket of projects or branch and will distribute the profit and loss of the Moshareka and perform account clearing.

The entrepreneur also by going to the PLS banking branch will offer her investment Moshareka project to the bank. The bank by declaring the conditions and regulations of Moshareka to the customer through the information portal of bank's Moshareka Certificates or information counter located in the PLS branch pays a document fee (according to its instruction) and bank will receive the proposal of the project with detailed economic, technical and financial feasibility reports and other related information. Entrepreneur evaluation unit according to the background of the entrepreneurs and according to specific instructions will evaluate the entrepreneur and in case of a positive evaluation of technical ability and expertise of entrepreneur will send the related reports to the project evaluation unit. In case of a positive evaluation of the project, project evaluation unit will determine the type and amount of collaterals, guarantees, and Moshareka share according to the specified instructions. The arrangement will be transmitted to the entrepreneur. After making the contract, the requested and approved resources will be paid to the entrepreneur through the contracted Moshareka contract. The whole documents (according to related instructions) including: budgeting, timing plan, resource needs and resource consuming manner, project implementation, phasing, quality control, reporting, ending and delivering of the project should be delivered to Amin (trustee) of the project by the entrepreneur. The reports of supervision on the project and the quality of performance of the entrepreneur should be delivered to the accounting/auditing bureau of the bank according to the predetermined time schedules. It is obvious that the reports of the Amin of the project will be the criteria of the following payments of the bank to entrepreneur. At the end of the project and according to the instructions and formulas relating to the amount of profit and loss of the project and the Karmozd (wage) of the bank or her share will be calculated by the software of accounting/auditing bureau. The share of the entrepreneurs and the depositors will also be determined and will be transferred to their accounts. In the case of reports of Amin regarding stop or delay of the project, the amount of delay, and the loss caused by the delay will be calculated according to the given instructions.

\section{NUBankCo: Structures and Instruction Codes}

All of the activities in this method will be done based on compiled instructions. The framework and the organization of PLS banking are organized has been analyzed in forms of required committees, units and departments tailored for the above definitions. All the operations will be done according to the following prewritten instructions:

- Instruction for evaluating the entrepreneur's ability including some guidepost about technical capabilities and financial background, a grouping of entrepreneurs regarding the type of project and types of collaterals and guarantees and previous commitments and share of investment of the entrepreneur, in three class of green, yellow and red

- Instruction for guarantees, hypothecs, and initial capital

- Instruction for necessary documents for evaluation of the project

- Instruction for receipts of bank

- Instruction for standards and obligations for supervision

- Instruction for reporting of entrepreneurs

- Accounting and auditing instructions

- Instructions for changes in timing and cost, including inflation effects on income and cost and net return of the project, and also the negligence of entrepreneurs resulting in a delay of commitments and changes in the timing of the projects

- Instruction for new Moshareka (increasing the capital during the implementation of the project)

- Instruction for clearing and the settlement of the account of the entrepreneur

- Instruction for arbitration

- $\quad$ Force majeure instruction

- Instruction for writing the PLS contract including Moshareka Certificate and the contract between bank and depositor, bank and Amin, Bank and entrepreneur

- Instruction for the capability of Amin 
- Instruction for dispensing of depositors and premature account clearing

- Instruction for transforming Moshareka Certificate into corporation share in production projects

- Instruction for transacting Moshareka Certificate

- Instruction for Moshareka Certificate secondary market internet platform including information portal, registration and membership, proposing purchase/sale, communicating between seller and purchaser of Moshareka Certificate, registration and inquiry

The structure and organization of PLS banking regarding the above definition will be done within a frame of:

- Strategic decision-making committee in PLS Banking.

- Expert group for interpreting and revision of regulations and processes of PLS banking

○ PLS office including:

- Legal Bureau

- Project evaluation bureau

- Auditing/accounting bureau

- Financial engineering management bureau (back office)

- Amin (trustee) bureau

- PLS branch

- Information and consulting services bureau

- Cash bureau

To facilitate the Moshareka certificate operations, a bill of "Regulations of issuing Moshareka certificate for PLS banking" has been written to be ratified and be approved by the government. Auxiliary financial instruments and innovations are about Moshareka Certificates Baskets regarding risk determination in economic activities and determination of the weights of economic activities in the basket; and classification of Moshareka Certificate Baskets; and Moshareka Certificate Insurance; and typical contracts and usable forms in PLS banking.

In the pilot stage, a test of this type of banking can be done by establishing a corporation inside a branch of an ordinary bank, or by establishing a new branch for executing this type of banking. In the first case, the banking activity of PLS will be done in parallel with other activities of the branch, but all financial, accounting, organizational and structural operations are separated from a legal point of view and are due to the newly established institute/corporation.

We are convinced that the current PLS system and NUBankCo will serve the entire humanity and contribute to increasing wealth and abundance in the entire globe.

\section{Executive Implementation}

Many economists around the world have done their best to eliminate Riba from banking activities, but have not achieved much. In this direction, Rastin Banking, in compliance with Sharia commands, has been compiled not only to eliminate Riba but also to institutionalize various teachings of justice and Islamic ethics in banking activities. Good points of Rastin Banking in all fields of banking, financial, economic, ethical, social, and international activities are so expanded that it can be regarded as a base to improve banking structure.

To increase the compliance of banking system with principles and regulations of Islamic religion, and better access to safe financial activity and helping the economy to bloom, fair distribution of possibilities and opportunities, job creation and increasing the welfare of the society, the Rastin Banking System was designed and all banks can carry out their activities on this basis.

Rastin Banking System is based on special operational, financial, economic, ethical, social, legal, international and organizational principles that based upon the latest scientific achievements of humankind in the field of science and technology with the aim of growth and development of the economy and banking of the society.

In order to facilitate legal activities of Rastin Banking, some improvements have been carried out on auxiliary Islamic contracts. To fulfill the necessary legislative needs of bank sharing activities, joint investment funds and facilitating social insurance activities, some new legal institutions are also defined as "Fund with variable capital". To distinguish profit from Riba, certain measures were also defined.

In order to prevent squandering (Israf) and to reform banking sources consumptions, which have worse economic and social consequences than Riba, and to increase efficiency, the bank is obliged to follow specific regulations concerning its activities and finance only those projects, which have observed certain considerations and criteria in their project proposal.

Bank can finance projects of restoring uncultivated lands by supporting qualified applicants for the promotion of employment and development of agriculture, industry, mining, housing, and tourism in the development of different regions of the country.

Bank and parties involved in Rastin Banking contracts should observe the supervisory compiled regulations concerning financial transparency, information disclosure, and corporate governance. All contracts with the bank are 
considered as official documents and enforceable. These contracts will be carried out by a unit of execution of enforceable documents in the bank.

\section{Rastin PLS Banking}

In Rastin PLS banking as the main subsection of Rastin Banking, on behalf of the depositor, the bank finances entrepreneur for investment according to compiled regulations, and at the end project, the entrepreneur will distribute the profit/loss of the project in proportion to capital and duration of using that capital with the depositor.

\section{Rastin PLS Base System}

Rastin PLS Base system refers to the main process and general regulations of Rastin Profit and Loss Sharing (PLS) Banking system. On request and on behalf of the depositor, the bank invests his fund in one of Rastin PLS products and instead, gives Rastin Certificate of the selected project to him and allocates his fund to the selected project of the entrepreneur; and supervises the implementation and execution of the project. In the end, after deducting its own commission, bank divides the profit/loss (if any) among engaged sides (depositors and entrepreneur). The bank is the agent of the depositor and is responsible for observing his rights (depositor). He must use all his expertise to reach this end.

The fixed profit rate is eliminated in Rastin PLS banking, and the return rate is calculated according to the real return of capital in the real economy. Most of the regulations of Rastin PLS Base system are extended to its financial subsystems. This system has its own organization, structure, and working process.

\section{Rastin PLS Financial Subsystems}

Rastin PLS financial subsystems refer to specific financing methods or services in Rastin PLS Banking. These subsystems work under general regulations of Rastin PLS Base system:

- Joalah Financial Sharing (JFS): is a method in which the bank finances entrepreneur (producer) from depositor's resources or the provided sources by the buyer.

- Mudarabah Financial Sharing (MFS): is a kind of mudarabah under Rastin PLS banking in which bank introduces the entrepreneur project proposal in the field of trade or transaction of commodities (commerce) to depositors.

- Installment Financial Sharing (IFS): in IFS, the installer (depositor) will finance a portion of the needed fund of the entrepreneur through the bank for a certain period of time (amortization period). The entrepreneur will pay back his share by installments and will own the total property of the project, and IFS ends.

- Rent Financial Sharing (RFS): entrepreneur temporarily donates the ownership of a part of his productive asset (assets of an operating firm), rental asset (those assets, which can be let) or dead asset (non-operating or suspended firms or uncultivated lands assets) to depositor who finances him but keeps it as mortgage. Then pays back the fund received from the yields of the asset proportional to depositor's share to depositor at the end of the contract, or periodically. The original deposit of depositor will be given back to him after the end of the project. The profit of the project will be given to depositor periodically or in a lump.

- Bail Financial Sharing (BFS): is the application of deposit of depositor by the entrepreneur to produce a defined commodity and delivering the commodity or paying back its value in a future specified time.

- Rastin Group Funding (RGF): is collecting deposits of specific depositors for a specific beneficial project under the regulations of Rastin Banking.

- Rastin Personal Security (RPS): to create competitive conditions and to increase the efficiency of social security insurance and diminishing antitrust of social security systems and pension funds, private and public pension funds are established according to Rastin Banking regulations. People and firms can allocate a portion of their obligatory (or optional) insurance premium payments (for himself or his employees) for social security to the funds that operate under Rastin Personal Security (RPS) and enjoy its benefits. Therefore, they will be exempted from obligatory insurance premium payments equal to the payment they have paid to these funds.

- Rastin Social Takaful (RST): benevolent people can deposit their funds at banks for charity purposes, and the bank will be allowed to pay profit (or the principal as well) of deposit to needy people, in the form of a loan or non-returnable payments (according to the depositor request).

- Sponsor Crowd Funding (SCF): is the process of collecting non-returnable funds for a specific protective goal of an entrepreneur through the bank via social networks.

- Peer to Peer Loan (PPL): is the process of collecting funds for loan-financing the entrepreneur through the bank and via social networks.

- Rastin Swap Bond (RSB): is based upon Mubadalah (swap) contract between Mobadil (swapper) and Motebadil (swapee) in which the durations and substances of swaps are equal for first and second swaps. Motebadil (swapee) issues the bond and owes to Mobadil equal to the nominal value of the bond, and 
should pay this amount (badal) to Mobadil (swapper) at maturity. The issuer (Motebadil) is obliged to give the mobaadal for the same amount and period as badal to mobadil. He can choose a combination of amount and period that the multiplication of amount by the period of mobaddal be equal to that of badal. At second maturity, mobadil is committed to returning mobaddal to motebadil.

- No interest rate is involved in these bonds, and they are of four kinds: Central Bank Rastin Swap Bond, Treasury Rastin Swap Bond, Bank Rastin Swap Bond, and Commercial Rastin Swap Bond. They can be in domestic money or foreign exchange.

- Rastin Swap Deposit (RSD): is a new banking deposit account, which is interest-free and is based on Swap Contract in Rastin Banking. In this depositing by opening the deposit, the depositor is entitled to use an interest-free loan to the amount and duration that his resources have been being deposited and then return the money back to the bank.

- Rastin Swap Card (RSC): is a bank card, and has no interest rate and is issued based on the Swap Contract in Rastin Banking. In Rastin Swap Card there are two periods. In the first period, card issuer lends money to the cardholder; and in the second period borrows money from cardholder instead. At the first stage cardissuer credits a certain amount of money for specific time duration to the card of cardholder and requests the cardholder to deposit the same amount for the same period at the end of the cited time duration (first maturity) in the issuer's deposit account.

\section{Rastin Certificates}

Rastin Certificates are a collection of designed certificates in Rastin PLS Banking Base system and its financial subsystems. These certificates can be anonymous or named papers, which are transferable and negotiable online through the website of the bank and are issued with a nominal price and for a certain period. The owners of these certificates share the results of the project proportional to nominal price and participation period of the certificate.

Various Rastin Certificates and their characteristics according to the kind of participation in the PLS Base system or its financial subsystems regarding the type of project and the asset used as:

- PLS Base: Musharakah (Participation) and Pazireh (Subscripted) Certificates.

- JFS: Future Certificate.

- MFS: Mudarabah and Periodic Mudarabah Certificates.

- IFS: Ordinary Mughasatah (installment), Rental Mughasatah, and Musharakah Mughasatah Certificates.

- RFS: Mortgage Sharing, Periodic Mortgage Sharing, Mortgage Mudarabah (commerce), Periodic Mortgage Mudarabah, Mortgage Muzaraah (cultivating), Periodic Muzaraah, Mortgage Mugharasah (planting), Periodic Mortgage Mugharasah, Mortgage Musaghah (irrigation), Periodic Mortgage Musaghah, Mortgage Istisna (industrial/manufacturing), Periodic Mortgage Istisna and Rental Certificates.

- BFS: Bail Certificate.

- RPS: Social Security, Personal Security and Pension Security Certificates.

- $\quad$ RST: Takaful and Loan Certificates.

\section{Complementary Systems}

Complementary systems of Rastin Banking refer to innovations, platforms, and supplementary Rastin Banking methods and include the following systems:

- Rastin Certificate Market (RCM): is a web-based settlement system for the transaction of interest-free Rastin Certificates and Rastin Swap Bond in Rastin PLS bank.

- Crowd Funding System (CFS): this system is a web-based system, which collects funds for Sponsor Crowd Funding (SCF) and Peer to Peer Loan (PPL) projects via social networks.

- Operation Control and Monitoring System (OCM): is a computerized web-based system that provides the possibility of online inspection and control of bank personnel activities.

- Mortgage Securitization System (MSS): this system facilitates people to change their assets into Guarantee Certificates through the bank.

- Collateral Registration System (CRS): is an online web-based integrated system for registering movable and immovable assets.

- Serial Commitments Clearance (SCC): provides the necessary arrangements for settlement of obligations of people who are in debt to someone from one hand, while they are creditors to someone else in a chain of debits and credits in a set of people.

- Interbank Withdrawal Protocol (IWP): is an interbank agreement that allows the bank to withdraw its claims online from other debtor's accounts o at different banks when the debtor's account at the agent bank is empty. 
- Non-usury Scripless Security Settlement System (NSSSS): this is an online integrated web-based settlement system at the central bank for the transaction of Rastin Certificates and Rastin Swap Bonds coordination and supervision.

- Money Laundering Detection System (MLD): provides necessary structural and electronic basis to compare

\section{Conclusion} tax information and bank information to discover money laundering.

To design operational Islamic banking, we tried to mix theoretical and experimental knowledge to develop Rastin Banking. Rastin Banking is a completely new solution to banking based on Islamic and ethical teachings with the scientific and technological approach.

Some parts and modules of Rastin Banking have been implemented in Bank Melli Iran. The installed parts of the system are now functioning and have attracted depositors and investors, and since the procedures and instructions are well defined, the bank's staff is performing its procedures easily. The results of the test system are very satisfactory.

Rastin Banking is a nationwide project with lots of subtle technical points. This system is an open-source banking model, and all banks around the globe can easily install and use it. We wish Rastin Banking could put important steps to remove Riba and establish Islamic banking throughout the globe.

\section{References}

The Persian and English documents of Rastin Banking, including a detailed explanation of this banking method, are accessible through http://www.bidabad.com in full texts in Persian and English languages. "Draft of Rastin Banking Bill" and its "Operational Bylaw of Rastin Banking" can also be accessed through the cited link.

Bidabad, Bijan, New Operational Islamic Banking System, Volume One, Theoretical Foundations, Lap Lambert Academic Publishing, OmniScriptum GmbH \& Co. KG, 2014, ISBN: 978-3-659-54463-7.

http://www.amazon.com/Rastin-Banking-Operational-TheoreticalFoundations/dp/3659544639/ref=sr_1_2?s=books\&ie=UTF8\&qid=1402563518\&sr=1-2

http://pub.npdr.ir/product/rastin-banking/

Bidabad, Bijan, New Operational Islamic Banking System, Volume Two, Applicational Issues, Lap Lambert Academic Publishing, OmniScriptum GmbH \& Co. KG, 2014, ISBN: 978-3-659-55210-6.

http://www.amazon.com/Rastin-Banking-II-OperationalApplication/dp/3659552100/ref=sr_1_1?s=books\&ie=UTF8\&qid=1404643353\&sr=1-1

http://pub.npdr.ir/product/rastin-banking-volume-ii/

Bidabad, Bijan, Economic-juristic analysis of usury in consumption and investment loans and contemporary jurisprudence shortages in exploring legislator commandments. Proceeding of the 2nd International Islamic Banking Conference. The Monash University of Malaysia. 9-10 September 2004. Reprinted in: National Interest, Journal of the Center for Strategic Research, Vol. 2, No. 1, winter 2006, pp. 72-90. Tehran, Iran. Republished in (revised): International Journal of Islamic Business \& Management, 3(2), 115, 2019 .

https://www.cribfb.com/journal/index.php/ijibm/article/view/275

http://www.bidabad.com/doc/reba-en.pdf

Bidabad, Bijan, Non-Usury Bank Corporation (NUBankCo), The Solution to Islamic banking, Proceeding of the 3rd International Islamic Banking and Finance Conference, The Monash University, KL, Malaysia, 16-17 November, 2005. International Journal of Shari'ah and Corporate Governance Research, 2(1), 53-66, 2019 .

https://www.cribfb.com/journal/index.php/ijscgr/article/view/276

http://www.bidabad.com/doc/NUBankCo-en.pdf

Bidabad, Bijan, Mahmoud Allahyarifard. IT role in fulfillment of Profit \& Loss Sharing (PLS) mechanism. Proceeding of the $3^{\text {rd }}$ International Islamic Banking and Finance Conference, The Monash University, KL, Malaysia, 16-17 November, 2005. International Journal of Islamic Banking and Finance Research, 3(2), 44-59, 2019.

https://www.cribfb.com/journal/index.php/ijibfr/article/view/274

http://www.bidabad.com/doc/english-pls-5.pdf

http://www.bidabad.com/doc/pls-it-en.ppt

Bidabad, Bijan, Mahmoud Allahyarifard. Implementing IT to Fulfill Profit \& Loss Sharing Mechanism. Islamic Finance News (IFN), Vol. 3, Issue 3, 6, February 2006, pp. 11-15.

http://www.bidabad.com/doc/summery-pls-it-1.pdf 
Bidabad, Bijan; Mahmoud Allahyarifard. Assets and Liabilities Management in Islamic Banking. Proceeding of the $3^{\text {rd }}$ International Conference on Islamic banking and Finance, Risk Management, Regulation and Supervision, Bidakara, Jakarta, Indonesia, 23-26 February, 2010. pp. 396-413. International Journal of Islamic Banking and Finance Research, 3(2), 32-43, 2019. Retrieved from:

https://www.cribfb.com/journal/index.php/ijibfr/article/view/272

http://www.bidabad.com/doc/alm-english.pdf

Bidabad, Bijan. Non-Usury Banking Fits to Obama's Change Strategy, the Solution to Revive the Economy.

http://www.bidabad.com/doc/PLS-paper-en-5.pdf

Bidabad, Bijan, Mahmoud Allahyarifard. The Executive Mechanism of Profit and Loss Sharing (PLS) Banking. 2009.

http://www.bidabad.com/doc/PLS-banking-Executive-Mechanism.pdf

Bidabad, Bijan, Mahmoud Allahyarifard. IT Based Usury Free Financial Innovations. Proceeding of ECDC 2010, 5th International Conference on e-Commerce in Developing Countries: with focus on e-Banking \& eInsurance. ECDC 2010, 15-16 September 2010.

http://www.bidabad.com/doc/non-usury-finance-it-en.pdf

Bidabad, Bijan, Mahmoud Allahyarifard. Usury-Free Bonds and Islamic Central Banking Monetary Instruments. 2010.

http://www.bidabad.com/doc/Islamic-banking-bond-en.pdf

Bidabad, Bijan, Stabilizing Business Cycles by PLS Banking and Ethic Economics. 2010.

http://www.bidabad.com/doc/pls-business-cycles-en.pdf

Bidabad, Bijan, Mahmoud Allahyarifard. Accounting Procedures for Profit and Loss Sharing (PLS) Banking. 2010. http://www.bidabad.com/doc/PLS-accounting-en.pdf

Bidabad, Bijan, Abul Hassan, Ben Ali Mohamed Sami, Mahmoud Allahyarifard. Interest-Free Bonds and Central Banking Monetary Instruments. International Journal of Economics and Finance. Vol. 3, no. 3, Aug 2011, pp.234-241.

http://www.ccsenet.org/journal/index.php/ijef/article/download/11665/8300

Bidabad, Bijan, Fluctuations and Business Cycles Prevention by New Financial Instruments and Banking Structure Reform. 2011.

http://www.bidabad.com/doc/Fluctuations-and-Cycles.pdf

Bidabad, Bijan, Mudarebah Financial Sharing (MFS). Journal of Islamic Economics, Banking and Finance, JIEBF, Volume - 10, Number - 1, January - April 2014, pp. 56-68.

http://www.bidabad.com/doc/mfs-paper-en.pdf

http://ibtra.com/pdf/journal/v10_n1_article3.pdf

Bidabad, Bijan, Joalah Financial Sharing (JFS). Journal of Islamic Economics, Banking and Finance, Volume-12, No. 1, January-March, 2016, pp. 33-48.

http://www.bidabad.com/doc/jfs-paper-en.pdf

http://ibtra.com/pdf/journal/v12_n1_article2.pdf

Bidabad, Bijan,Interest-Free Treasury Bonds (IFTB), 2011.

http://www.bidabad.com/doc/interest-free-t-bond-en.pdf

http://www.bidabad.com/doc/iftb-en.pptx

Bidabad, Bijan, Interest-Free Treasury Bonds (IFTB), Islamic Finance and Legal Clarifications, 2011. International Journal of Islamic Business \& Management, 3(1), 21-29, 2019.

http://www.bidabad.com/doc/interest-free-t-bond-feqhi-en.pdf

https://www.cribfb.com/journal/index.php/ijibm/article/view/258/353

Bidabad, Bijan, Abul Hassan, Ben Ali Mohamed Sami, Mahmoud Allahyarifard. Interest-Free Bonds Financial Innovation, A Monetary Instrument for Economy at Crisis. Journal of Economic Cooperation and Development (JECD). 32, 1, 2011, 55-70.

http://www.sesric.org/jecd/jecd_articles/ART10102201-2.pdf

Bidabad, Bijan, Deposits and Loans Interest Rates Lag Structure and Business Cycles (Case Study of United States). 2011.

http://www.bidabad.com/doc/Interest-Rates-Lags-and-Cycles.pdf

Bidabad, Bijan, Installment Financial Sharing (IFS): A Financial Subsystem of Rastin PLS Banking. International Journal of Islamic Banking and Finance Research, 3(1), 28-42, 2019.

https://www.cribfb.com/journal/index.php/ijibfr/article/view/267

http://www.bidabad.com/doc/ifs-paper-en.pdf

Bidabad, Bijan, Abul Hassan, Does Interest Rate Form Business Cycle, 2011. 
http://www.bidabad.com/doc/interest-rate-cycle.pdf

Bidabad, Bijan, Rent Financial Sharing (RFS). Journal of Islamic Economics, Banking and Finance, 2014.

http://www.bidabad.com/doc/rfs-paper-en.pdf

http://ibtra.com/pdf/journal/v10_n2_article2.pdf

Bidabad, Bijan, Rastin Social Takaful (RST). Journal of Islamic Economics, Banking and Finance, JIEBF, Volume

- 11, Number - 1, January - March 2015, pp.: 13-23.

http://ibtra.com/pdf/journal/v11_n1_article1.pdf

http://www.bidabad.com/doc/rst-paper-en.pdf

Bidabad, Bijan, Mortgage Securitization System (MSS), A Complementary System of Rastin Banking. International Journal of Law and Management (IJLMA), Vol. 59 Issue: 6, pp.778-783, 2017. Emerald Group Publishing Limited

https://doi.org/10.1108/IJLMA-05-2016-0045

http://www.bidabad.com/doc/mss-paper-en.pdf

Bidabad, Bijan, Bail Financial Sharing (BFS): A Financial Subsystem of Rastin PLS Banking. Bank Melli Iran, Tehran, Iran, 2014. International Journal of Islamic Banking and Finance Research, 3(1), 21-27, 2019.

https://www.cribfb.com/journal/index.php/ijibfr/article/view/266

http://www.bidabad.com/doc/bfs-paper-en.pdf

Bidabad, Bijan, Rastin Personal Security (RPS). Journal of Islamic Economics, Banking and Finance, JIEBF, Volume - 11, Number - 2, April - June 2015, pp. 47-61.

http://ibtra.com/pdf/journal/v11_n2_article3.pdf

http://www.bidabad.com/doc/rps-paper-en.pdf

Bidabad, Bijan, Joint Stock Company with Variable Capital (JSCVC), International Journal of Law and Management (IJLMA), Emerald Group Publishing Limited, Vol. 56, Iss: 4, pp.302 - 310, 2014.

http://dx.doi.org/10.1108/IJLMA-09-2012-0031

http://www.bidabad.com/doc/vjsc-paper-en.pdf

Bidabad, Bijan, Rastin Profit and Loss Sharing (PLS) Base System. Journal of Islamic Economics, Banking and Finance, pp. 32-57, Vol. 9, No. 4, Oct-Dec 2013.

http://ibtra.com/pdf/journal/v9_n4_article2.pdf

http://www.bidabad.com/doc/pls-base-en.pdf

Bidabad, Bijan, Money Laundering Detection System (MLD), A Complementary System of Rastin Banking, Journal of Money Laundering Control, Vol. 20 Issue: 4, pp. 354-366, 2017.

https://doi.org/10.1108/JMLC-04-2016-0016

http://www.bidabad.com/doc/mld-paper-en.pdf

Bidabad, Bijan, Nikos Mastorakis, General Characteristics of Rastin Banking. Proceeding of the 3rd International Conference on Economics, Political, Law and Fiscal Sciences (EPLS '14), World Scientific and Engineering Academy and Society (WSEAS). Transilvania University of Brasov, Brasov, Romania, June 26-28, 2014.

http://www.bidabad.com/doc/rastin-bank-general-en.pdf

http://www.bidabad.com/doc/rastin-bank-general-en.ppt

Bidabad, Bijan, A glance at Rastin Banking, 2013.

http://www.bidabad.com/doc/rastin-bank-glance-en.pdf

Bidabad, Bijan, Rastin Banking, New Operational Islamic Banking System (A bird's eye view). Islamic Finance News (IFN), Vol. 10, Issue: 28, 17, July, 2013, pp. 16-18.

http://www.bidabad.com/doc/rastin-bank-bird-eye-view-en.pdf

Bidabad, Bijan, Islamic Monetary Policy, 2013. International Journal of Islamic Banking and Finance Research, $3(2), 1-16,2019$.

https://www.cribfb.com/journal/index.php/ijibfr/article/view/269 http://www.bidabad.com/doc/islamic-monetary-policy-en.pdf

Bidabad, Bijan, Rastin Certificate Market (RCM), Complementary System of Rastin Banking, 2013. International Journal of Islamic Business \& Management, 3(1), 35-43, 2019.

https://www.cribfb.com/journal/index.php/ijibm/article/view/260

http://www.bidabad.com/doc/rastin-bank-rcm-en.pdf

Bidabad, Bijan. Sovereign Wealth Fund Asset and Liability Management by Rastin Banking Financial Instruments (Rastin Certificates and Rastin Swap Bonds), First National Development Fund of Iran (NDFI) International Conference (NIC2013) - Sovereign Wealth, Asset Allocation and Risk Management, Kish Island, Persian Gulf, Iran, NIC 2013, 27-28 October 2013. 
http://www.bidabad.com/doc/swf-alm-en.pdf

Bidabad, Bijan, Mahmoud Allahyarifard, Interbank Withdrawal Protocol (IWP), Complementary System of Rastin Banking 2013. International Journal of Islamic Business \& Management, 3(1), 30-34, 2019.

https://www.cribfb.com/journal/index.php/ijibm/article/view/259

http://www.bidabad.com/doc/iwp-paper-en.pdf

Bidabad, Bijan, Roohollah Mohammadi; Mahshid sherafati, Social Takaful and Qard ul-Hassanah Banking Convergences (A Functional Approach), Journal of Applied Science and Agriculture (JASA) November issue 2013.

http://www.bidabad.com/doc/takaful-en.pdf

Bidabad, Bijan, Change Management of Banking System at National Level by Rastin Banking (Knowledge Management, Empowerment, Prune and Graft, and Apprenticeship), presented at the 10th International Conference on Economics and Management, Islamic Azad University, Rasht, Iran, 2017. Review of Behavioral Aspect in Organizations and Society, 2019, 1(1), 11. Review of Behavioral Aspect in Organizations and Society, 1(1), 57-70 .

https://doi.org/10.32770/rbaos.vol157-70

http://www.bidabad.com/doc/change-banking-en.pdf

http://www.bidabad.com/doc/change-banking-en.pptx

Bidabad, Bijan, Insurance Products in Rastin Banking, 2014.

http://www.bidabad.com/doc/rastin-insurance-en.pdf

Bidabad, Bijan, Abul Hassan, Nikos Mastorakis, Dynamic Lag Structure of Deposits and Loans Interest Rates and Business Cycles Formation. Proceeding of the 3rd International Conference on Economics, Political, Law and Fiscal Sciences (EPLS '14), World Scientific and Engineering Academy and Society (WSEAS). Transilvania University of Brasov, Brasov, Romania, June 26-28, 2014.

http://www.bidabad.com/doc/interest-rates-cycle-en.pdf http://www.bidabad.com/doc/interest-rates-cycle-en.ppt

Bidabad, Bijan, Rastin Crowdfunding (RCF): A Financial Subsystem of Rastin Banking. Bank Melli Iran, Tehran, 2014. International Journal of Islamic Banking and Finance Research, 3(1), 13-20, 2019.

https://www.cribfb.com/journal/index.php/ijibfr/article/view/265

http://www.bidabad.com/doc/rcf-paper-en.pdf

Bidabad, Bijan, Rastin Group Funding (RGF): A Financial Subsystem of Rastin Banking. Bank Melli Iran, Tehran, 2014. International Journal of Islamic Banking and Finance Research, 3(1), 43-48, 2019.

https://www.cribfb.com/journal/index.php/ijibfr/article/view/268

http://www.bidabad.com/doc/rgf-paper-en.pdf

Bidabad, Bijan, Mahshid Sherafati, Bank Information Disclosure, Financial Transparency and Corporate Governance in Rastin Banking, International Journal of Shari'ah and Corporate Governance Research, 2(1), 1-13.

https://www.cribfb.com/journal/index.php/ijscgr/article/view/257

http://www.bidabad.com/doc/shafafiyat-en.pdf

Bidabad, Bijan, Mahshid Sherafati, Financial Transparency, Governance and Public Disclosure for Entrepreneur (Financial Resource Receiver) in Rastin Banking System. Tehran, Iran, 2015.

http://www.bidabad.com/doc/transparency-entrepreneur-en.pdf

Bidabad, Bijan, Azarang Amirostovar, Mahshid Sherafati, Financial Transparency, Corporate Governance and Information Disclosure of the Entrepreneur's Corporation in Rastin Banking. International Journal of Law and Management (IJLMA), Emerald Group Publishing Limited, Vol:59, Iss:5, pp.636-651, 2017.

https://doi.org/10.1108/IJLMA-01-2016-0003

Bidabad, Bijan, Mahshid Sherafati, Proposed Regulations for Enforcement of Purports of Binding Banking Documents in Rastin Banking, Tehran, 2015.

http://www.bidabad.com/doc/rastin-bank-ejraye-asnad-en.pdf

Bidabad, Bijan, Saeed Abdollahi, Mahshid Sherafati, Enforcement of the Purports of Binding Banking Documents in Rastin Banking - Part I. International Journal of Law and Management (IJLMA), Emerald Group Publishing Limited, Vol:59, Iss:1, pp. 52-65, 2017.

https://doi.org/10.1108/IJLMA-07-2015-0041

Bidabad, Bijan, Saeed Abdollahi, Mahshid Sherafati, Enforcement of the Purports of Binding Banking Documents in Rastin Banking - Part II. International Journal of Law and Management (IJLMA), Emerald Group Publishing Limited, Vol:59, Iss:2, pp.178-191, 2017.

https://doi.org/10.1108/IJLMA-10-2015-0055 
Bidabad, Bijan, Mahshid Sherafati, Sustainable Financing and Anti-Squandering Measures in Rastin Banking. International Journal of Law and Management (IJLMA), Emerald Group Publishing Limited, Vol: 59, Issue: 6, pp. 939-949, 2017.

https://doi.org/10.1108/IJLMA-04-2016-0037

http://www.bidabad.com/doc/esraf-bank-resource-en.pdf

Bidabad, Bijan, Serial Commitments Clearance (SCC) in Rastin Banking. International Journal of Law and Management (IJLMA), Vol. 57, Iss: 6, 2015, pp. 600-609, Emerald Group Publishing Limited.

http://dx.doi.org/10.1108/IJLMA-02-2015-0007

http://www.bidabad.com/doc/scc-paper-en.pdf

Bidabad, Bijan, Rastin Swap Deposit (RSD): A Financial Account of Rastin Banking. Tehran, 2015. International Journal of Islamic Banking and Finance Research, 3(2), 17-23, 2019.

https://www.cribfb.com/journal/index.php/ijibfr/article/view/270

http://www.bidabad.com/doc/rsd-paper-en.pdf

Bidabad, Bijan, Rastin Swap Card (RSC): A Financial Instrument of Rastin Banking. Tehran, 2015. International Journal of Islamic Banking and Finance Research, 3(2), 24-31, 2019.

https://www.cribfb.com/journal/index.php/ijibfr/article/view/271

http://www.bidabad.com/doc/rsc-paper-en.pdf

Bidabad, Bijan, Mahshid Sherafati, Operational Ethical Banking in Rastin Banking (Professional Ethics, Audit, Inspection, Control, Monitoring and Preservation). International Journal of Law and Management (IJLMA), Emerald Group Publishing Limited, Vol: 58, Iss: 4, 2016, pp. 416-443.

http://dx.doi.org/10.1108/IJLMA-07-2015-0037

http://www.bidabad.com/doc/rastin-ethic-banking-en.pdf

Bidabad, Bijan, Mahmoud Allahyarifard, Mahshid Sherafati, Rastin Partnership Accounting, 2016.

http://www.bidabad.com/doc/rastin-mosharekat-accounting-en.pdf

Bidabad, Bijan, Abul Hassan, Dynamic Lag Structure of Deposits and Loans Interest Rates and Business Cycles Formation. Journal of Financial Regulation and Compliance, Vol. 25 Issue: 2, pp.114-132, 2017.

http://dx.doi.org/10.1108/JFRC-09-2016-0078

Bidabad, Bijan, General Regulatory Framework in Rastin Profit and Loss Sharing Banking (Part I-Operational Context). Journal of Business and Finance in Emerging Markets, JBFEM, [S.1.], v. 1, n. 1, p. 11-26, may 2018. ISSN 2580-5568.

https://doi.org/10.32770/jbfem.vol111-26

http://www.bidabad.com/doc/rastin-regulatory-en-I.pdf

Bidabad, Bijan, General Regulatory Framework in Rastin Profit and Loss Sharing Banking (Part II-Legal Groundwork). Journal of Business and Finance in Emerging Markets, JBFEM, JBFEM, [S.1.], v. 1, n. 2, p. 109-126, nov. 2018. ISSN 2580-5568.

https://doi.org/10.32770/jbfem.vol1109-126

http://www.bidabad.com/doc/rastin-regulatory-en-II.pdf

Bidabad, Bijan, General Regulatory Framework in Rastin Profit and Loss Sharing Banking (Part III-Auxiliary Provisions). Journal of Business and Finance in Emerging Markets, JBFEM, May 2019, Vol 2, No. 1, pp. 51-65. ISSN 2580-5568.

https://doi.org/10.32770/jbfem.vol251-66

http://www.bidabad.com/doc/rastin-regulatory-en-III.pdf

\section{Copyrights}

Copyright for this article is retained by the author(s), with first publication rights granted to the journal. This is an open-access article distributed under the terms and conditions of the Creative Commons Attribution license (http://creativecommons.org/licenses/by/4.0/). 